\title{
Antioxidant biosensor based on superoxide dismutase from Indonesian microbes immobilized in Indonesian natural zeolite
}

\author{
Dyah Iswantini $^{1,3^{*}}$, Weniarti ${ }^{1}$, Novik Nurhidayat ${ }^{2}, Z$ aenal Abidin ${ }^{1}$, Trivadila ${ }^{1}$ \\ ${ }^{1}$ Department of Chemistry, Faculty of Mathematics and Natural Sciences, Bogor Agricultural University, Bogor, Indonesia. \\ ${ }^{2}$ Division of Microbiology R\&D for Biology, Indonesian Institute of Sciences, Bogor, Indonesia. \\ ${ }^{3}$ Tropical Biopharmaca Research Center, Bogor Agricultural University, Bogor, Indonesia.
}

\begin{tabular}{l}
\hline ARTICLE INFO \\
\hline Received on: 12/01/2018 \\
Accepted on: 04/08/2018 \\
Available online: 18/04/2019 \\
\hline Key words: \\
Antioxidant biosensor, \\
superoxide dismutase (SOD), \\
deinococcus radiodurans, \\
zeolite nanocomposite, \\
enzyme kinetics.
\end{tabular}

\begin{abstract}
Common techniques for measuring the capacity and activity of antioxidants are spectrophotometry, fluorescent, liquid and gas chromathography. The antioxidant measurement using spectrophotometry method has its limitation in sample preparation. Therefore, an appropriate method is needed to measure the antioxidant properties in various types of samples, either sample from natural or industrial products. Electrochemical biosensor is a developed alternative method to study the antioxidant capacity because its rapidity, validity and low cost. The immobilization of superoxide dismutase (SOD) extract from Deinococcus radiodurans on a zeolite nanocomposite-modified electrode was studied as an antioxidant biosensor. Cyclic voltammetry was employed to investigate the catalytic behavior of the immobilized-SOD in zeolite nanocomposite. The current response was found to have a direct linear relationship with xanthine (substrate) concentration. The immobilized-SOD activity was optimum at $30^{\circ} \mathrm{C}, \mathrm{pH} 9,137.5 \mathrm{mg}$ zeolite, and $1 \mu \mathrm{g} / \mathrm{ml} \mathrm{SOD}$ for pure SOD, and at $30^{\circ} \mathrm{C}, \mathrm{pH} \mathrm{9,137.5} \mathrm{mg} \mathrm{zeolite,} \mathrm{and} \mathrm{1,500} \mu \mathrm{g} / \mathrm{ml}$ SOD for D. radiodurans SOD. Dismutation reaction kinetics of superoxide catalyzed by SOD followed the Lineweaver-Burk plot for enzyme kinetics with an immobilized $D$. radiodurans SOD value smaller than for immobilized pure SOD. In conclusion, a zeolite nanocomposite provided great potential as an immobilization matrix for SOD extract from D. radiodurans for application in antioxidant biosensors.
\end{abstract}

\section{INTRODUCTION}

The body needs antioxidants to defend against free radicals and has endogenous antioxidants such as catalase, peroxidase, superoxide dismutase (SOD), and glutathione S-transferases. When the body is exposed to excessive free radicals, it requires exogenous antioxidants, which are usually obtained from food. Antioxidants are not only necessary for human health but are also widely used in commercial industries such as foods, petroleum, rubber, etc. Therefore, an appropriate method is

\section{${ }^{*}$ Corresponding Author}

Dyah Iswantini, Department of Chemistry, Faculty of Mathematics and Natural Sciences, Bogor Agricultural University, Bogor, Indonesia and Tropical Biopharmaca Research Center, Bogor Agricultural University, Bogor, Indonesia. E-mail: dyahprado@gmail.com needed for measuring the antioxidant properties in various types of samples from natural or industrial products.

Common techniques for measuring the capacity and activity of antioxidants are spectrophotometry, fluorescent, liquid and gas chromatography (Cortina-Puig and Camp, 2007). Spectrophotometry has its limitations for measuring antioxidants in sample preparations. For example, the 2,2-diphenyl-1picrylhydrazylmethod is highly sensitive to the light and necessitates samples preparation in the dark. In addition, it is greatly affected by turbidity levels. The 2,2-azinobis (3-ethylbenzothiazoline6-sulfonic acid) (ABTS) and ferric reducing antioxidant power methods are also highly sensitive to light, with the formation of ABTS needing 12-16 hours incubation time in the dark (Tawaha et al., 2007). Oxygen radical absorbance capacity-fluorescein and HPLC (High Performance Liquid Chromatography) methods also have limitations in measuring antioxidant capacity as they are expensive and involve difficult sample preparation. 
Electrochemical biosensors were developed as an alternative means for studying antioxidant capacity because of their rapidity, validity, and low cost (Campanella et al., 2004). There are two kinds of antioxidant biosensors: amperometric biosensors to detect monophenol and polyphenol antioxidants (the main antioxidants in foods); and biosensors using SOD for measuring antioxidant capacity based on free radical scavenging. Respectively, these are tyrosinase-, laccase-, or peroxidase-based biosensors (Cabaj et al., 2016; Garcia et al., 2015), while the latter use cytochrome $c(c y t c)$ or SOD, and DNA (Azizi et al., 2013; Braik et al., 2016; Busch et al., 2006; Campanella et al., 2005; Cortina-Puig and Camp, 2007; Kamel et al., 2008; Roy et al., 2005). Superoxide radical determination using cyt $c$-based sensors is less selective because this heme protein is not specific to $\mathrm{O}_{2}{ }^{--}$. SOD-based biosensors are more specific and sensitive because this enzyme specifically reacts with superoxide ion (Braik et al., 2016; Di et al., 2004).

SOD-based biosensors have been applied to measure antioxidant capacity in various kinds of samples, such as natural products, food and beverage products, and also algae (Braik et al., 2016; Campanella et al., 2003; 2005). One limitation of SOD utilization in biosensors is its high price. Therefore, the use of microbes that produce this enzyme is one cost-reducing solution as it does not require enzyme purification. One bacterium that produces SOD is D. radiodurans. Deinococcus radiodurans can survive under very high levels of radiation because this bacterium has rapid DNA repair mechanisms and has a lot of copies of its own genome. The quality of the bacterium, which is resistant to extreme environments, is expected because it has a high antioxidant system involving SOD and catalase (Yuan et al., 2007). Therefore, $D$. radiodurans has great potential as a biological recognition component of an antioxidant biosensor.

SOD-based antioxidant biosensor development has now reached its third generation and is also being directed toward nanoscale materials (Braik et al., 2016). One of the materials that could potentially be used as an immobilization matrix for SOD is zeolite. Zeolite has a structure largely composed of silicon tetrahedrons which are connected to each other by oxygen atoms to form typical nanoscale pores. The pores allow gas or liquid molecules to enter and adsorb them firmly. Applications of zeolite as immobilization matrices that have been developed include utilizing natural zeolite clinoptilolite as urea biosensors (Saiapina et al., 2011) and incorporating $\mathrm{NaA}$ zeolite with a carbon paste matrix to develop DNA-based antioxidant biosensors (Azizi et al., 2013). Indonesia is one country with natural zeolite potential but its utilization still needs to be optimized in all areas.

Though research has been carried out into the utilization of zeolite for sensors, Dai et al. (2003) immobilized $c y t$ - $c$ using a NaYtype zeolite matrix, while Liu et al. (1999) used calcined zeolite as an immobilization matrix for peroxidase and methylene green, and Balal et al. (2009) found carbon paste electrodes modified with $\mathrm{FeCl}_{3}$ and zeolite produced more current than those without zeolite - there have been no reports of the application of Indonesian natural zeolite nanocomposite as an immobilization material for $D$. radiodurans SOD. Accordingly, the use of natural zeolite nanocomposite was an interesting topic of study.

This study is a continuation of previous research conducted by Iswantini et al. (2013), which used D. radiodurans
SOD immobilized on carbon paste electrodes as an antioxidant biosensor. As the previous study was low in specificity and sensitivity, further study was necessary to determine immobilization methods and improvements in nanomaterials in order to obtain more favorable results. This aims of this study were to extract SOD enzyme proteins from $D$. radiodurans, immobilize them in a natural zeolite nanocomposite from Indonesia, measure their activity after fixation on the surface of carbon paste electrodes, and finally to determine their kinetic parameters using electrochemical methods.

\section{MATERIALS AND METHODS}

\section{Deinococcus radiodurans cell growth and SOD extraction}

Deinococcus radiodurans was grown in a medium containing $1 \%$ tryptone, $0.5 \%$ yeast extract, $0.2 \%$ glucose, $0.5 \% \mathrm{NaCl}$ and alcohol, and incubated for 48 hours at $30^{\circ} \mathrm{C}$. Subsequently, cells were harvested by centrifugation $(7,000 \mathrm{~g}$, $4^{\circ} \mathrm{C}, 10$ minutes) to separate the bacterial cells from the media. Next, the cells were washed several times with phosphate buffer solution $\mathrm{pH} 7.0$ and re-suspended in phosphate buffer solution $\mathrm{pH}$ 7.0. Cell suspension was lysed by sonication in an ice bath to break the bacterial cells and then centrifuged $\left(10,000 \mathrm{~g}, 4^{\circ} \mathrm{C}, 30\right.$ minutes $)$ to separate the supernatant and pellet. Enzyme crude extract was in the supernatant. Finally, the extract's absorbance values were measured at wavelengths of 260 and $280 \mathrm{~nm}$ to determine protein concentration and ratio of protein to DNA.

\section{Electrode modification and enzyme immobilization}

Enzyme immobilization was carried out through several methods: (a) Zeolite nanocomposite (250, 100, 50, and $25 \mathrm{mg}$ ) was suspended in $5 \mathrm{ml}$ of phosphate buffer solution containing crude extract of SOD. The mixture was then stirred constantly for 24 hours at $4{ }^{\circ} \mathrm{C}$. It was then centrifuged and the pellet was washed several times with $0.9 \% \mathrm{NaCl}$. The pellet was allowed to dry at $4^{\circ} \mathrm{C}$. This pellet was the immobilized SOD in the zeolite matrix. Five microliters of this pellet was then placed on the surface of a ferrocene-modified carbon paste (PCf) electrode and the surface was covered with a dialysis membrane and fixed with nylon fiber. This method was also done for pure SOD and D. radiodurans cells. This electrode was then called the "SOD/Zeolite/PCf" electrode. (b) Pure SOD was dropped directly onto the surface of a PCf electrode and the surface was covered with a dialysis membrane and fixed with nylon fiber. It was then called the "SOD/ PCf" electrode. (c) $100 \mathrm{mg}$ of zeolite was dissolved in distilled water to form a paste and then dropped onto the surface of a PCf electrode. The surface was covered with a dialysis membrane and fixed with nylon fiber. This was called the "Zeolite/PCf" electrode. (d) Zeolite nanocomposite was packed in a glass tube to fabricate a zeolite electrode, then the pure SOD solution was dropped onto its surface. This was called the "SOD/Zeolite" electrode.

\section{Electrochemical measurement}

Electrochemical measurement was carried out through a cyclic voltammetric (CV) method using eDAQ potentiostatgalvanostat equipped with Echem v2.1.0 software. $\mathrm{Ag} / \mathrm{AgCl}$, modified carbon paste, and Pt electrodes were used as references, as working and counter electrodes. Superoxide radicals were generated by the enzymatic reaction of xanthine as a substrate which was catalyzed by xanthine oxidase $(\mathrm{XO})$ through the reaction: 
Xanthine $+\mathrm{H}_{2} \mathrm{O}+\mathrm{O}_{2} \longrightarrow$ Xo $\longrightarrow$ Uric acid $+2 \mathrm{H}^{+}+\mathrm{O}^{-}$

Then, the superoxide radical was dismutated to form $\mathrm{O}_{2}$ with SOD as the catalyst.

$1.9 \mathrm{ml}$ of phosphate buffer solution and $100 \mu \mathrm{l}$ of 0.1 $\mu / \mathrm{ml}$ of $\mathrm{XO}$ were added into an electrochemical cell. Anodic current peak formed considered as blank. Subsequently, $1 \mathrm{ml}$ of xanthine $2.1 \mathrm{mM}$ was added to the cell and the current response change was observed and measured.

\section{Optimization of immobilized SOD activity}

The reaction conditions optimized were temperature $\left(20^{\circ} \mathrm{C}-40^{\circ} \mathrm{C}\right), \mathrm{pH}(7-11)$, SOD concentration, and zeolite mass (25-250 mg), with a central composite design of response surface method.

\section{Kinetic properties}

Kinetic properties has determined at the optimum conditions for SOD immobilization. The general procedure was the same, but in a kinetic assay, substrate concentration was varied between 0.00 and $1.00 \mathrm{mmol} / \mathrm{l}$ of xanthine concentration.

The kinetic properties of immobilized $D$. radiodurans SOD extract were determined using the Michaelis-Menten equation (Eq. 1):

$$
\mathrm{I}=\frac{I_{m}^{a p p}[\text { xanthine }]}{K_{m}^{a p p}+[\text { xanthine }]}
$$

where $I_{m}^{a p p}$ was the apparent measured maximum current response, $K_{m}^{a p p}$ was the apparent Michaelis-Menten constant, and [xanthine] was xanthine concentration.

Next, a Lineweaver-Burk plot was derived from Eq. 1.

\section{RESULTS AND DISCUSSION}

\section{Deinococcus radiodurans cell growth and SOD extraction}

Deinococcus radiodurans was grown in a liquid LB medium for 48 hours at $30^{\circ} \mathrm{C}$. After 48 hours, the cells were harvested to collect the crude extract of SOD protein. The extracted protein had a concentration of $3,100 \mu \mathrm{g} / \mathrm{ml}$ and the extract yield was $2.41 \%$ based on wet weight.

Using the same medium as that used in a previous study (Trivadila, 2011), the yield obtained in this study was higher. Another study obtained almost same results as this study, where the yield of Mn-SOD obtained from Thermotherix was 3,029 $\mu \mathrm{g} / \mathrm{ml}$

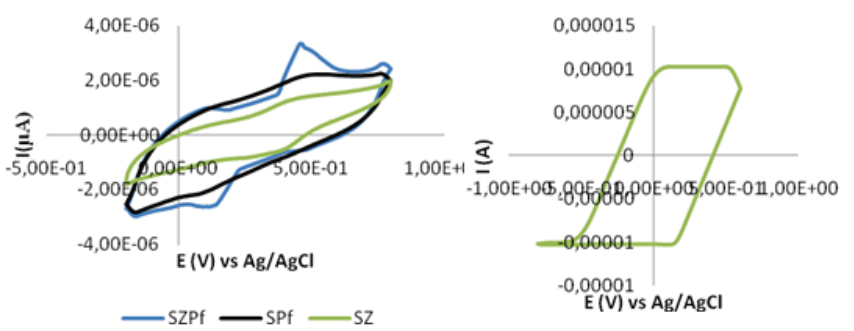

Figure 1. Anode and cathode current peaks for (a) SOD/Zeolite/PCf (SZPf), SOD/PCf (SPf), and SOD/Zeolite (SZ), and (b) anode and cathode current peaks for Zeolite/PCf (ZPf).
(Seatovic et al., 2004). The small value of D. radiodurans Mn-SOD was probably due to $D$. radiodurans having thicker and stronger cell walls than common bacteria and yeast cells. Deinococcus radiodurans contains thick peptidoglycan and an outer membrane on the outside of its cell walls (Battista, 1997). Further, D. radiodurans cells are tetrad-shaped and larger making it difficult to break them and extract their cytoplasm (Zimmerman and Battista, 2005).

\section{Enzyme immobilization}

An enzyme has high selectivity and sensitivity under normal conditions but is very sensitive and denatured easily by extremes in $\mathrm{pH}$ and temperature and by organic solvents and detergents (Takahashi et al., 2001). To retain the catalytic function of an enzyme under extreme conditions, the enzyme can be immobilized on the surface of solid support material such as zeolite nanocomposite. The selectivity and stability of an immobilized enzyme, in addition to being affected by a substrate, are also influenced by the immobilization method and the supporting material used.

Four modifications to immobilization methods were used: SOD was immobilized in zeolite then dropped on the surface of a ferrocene-modified carbon paste electrode (SOD/Zeolite/PCf); SOD immobilization on the surface of a ferrocene-modified carbon paste electrode (SOD/PCf); immobilization of zeolite on the surface of a ferrocene-modified carbon paste electrode (zeolite/PCf); and SOD immobilization on the surface of a zeolite electrode ( $\mathrm{SOD} /$ zeolite). Table 1 shows the current peak and potential for all immobilization methods. It shows that SOD/Zeolite/PCf generated the highest anodic current peak, while anodic and cathodic peaks for SOD/ Zeolite were lower than for both SOD/Zeolite/PCf and SOD/PCf. Figure 1a shows CV) for SOD/Zeolite/PCf, SOD/PCf, and SOD/ Zeolite. As Figure 1b shows an asymmetric CV generated from SOD immobilization on the surface of a zeolite electrode without ferrocene-modified carbon paste, it was difficult to determine its anodic and cathodic peaks. From these data, we may conclude that $\mathrm{SOD} /$ Zeolite/PCf produced more favorable results than the others.

The ability of zeolites to increase the current peaks generated has been shown in research conducted by Dai et al. (2003), in which the components of biological recognizers used were $c y t-c$ and $\mathrm{NaY}$ zeolite to detect $\mathrm{H}_{2} \mathrm{O}_{2}$. Adding $\mathrm{Fe}$ (III) to zeolite as a mediator on the carbon paste electrode could improve the oxidation and reduction peaks to detect dopamine and tryptophan (Balal et al., 2009). Zeolite-modified carbon paste electrodes produce higher currents than glassy carbon electrodes (Wan et al., 2009). The resulting current was also higher compared to a previous study (Iswantini et al., 2013), where SOD immobilized on a carbon paste electrode without zeolite produced an anodic peak current of $0.1 \mu \mathrm{A}$. The ability of zeolite

Table 1. Current and potential peaks for all immobilization methods.

\begin{tabular}{lcccc}
\hline Immobilization & \multicolumn{2}{c}{$\Delta \mathbf{I}(\boldsymbol{\mu} \mathbf{A})$} & & $\mathbf{E}(\mathbf{m V})$ versus Ag/AgCI) $(\mathbf{m V})$ \\
\cline { 2 - 5 } \multicolumn{1}{c}{ Method } & $\Delta \boldsymbol{I}_{p a}$ & $\Delta \boldsymbol{I}_{p c}$ & $\boldsymbol{E}_{p a}$ & $\boldsymbol{E}_{p c}$ \\
\hline SOD/Zeolite/PCf & 1.020 & 1.71 & 426 & 290 \\
SOD/PCf & 0.054 & 0.01 & 465 & 330 \\
Zeolite/PCf & 0.002 & 0.01 & 416 & 330 \\
SOD/Zeolite & 0.0012 & 0.00 & $\square 100$ & 115 \\
\hline
\end{tabular}

$\Delta I=$ current peak; $\Delta I_{p a}$ anodic current peak; $\Delta I_{p c}=$ cathodic current peak; $E=$ potential peak; $E_{p a}=$ anodic potential peak; $E_{p c}=$ cathodic potential peak. 

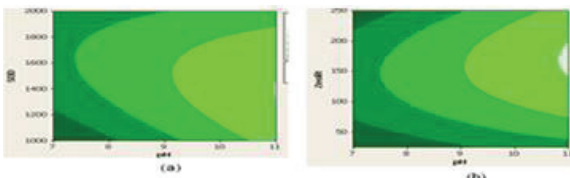

(b)
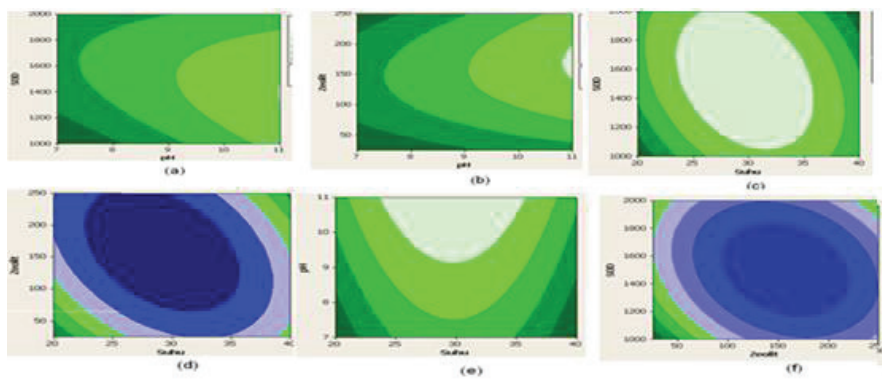

Figure 2. Contour plots of optimization conditions for immobilized $D$. radiodurans SOD activity, relationships between $\mathrm{pH}$, (a) SOD concentration and oxidation current peak, (b) $\mathrm{pH}$, zeolite and oxidation current peak, temperature, (c) SOD concentration and oxidation current peak, (d) temperature, zeolite, and oxidation current peak, (e) temperature, $\mathrm{pH}$, and oxidation current peak, (f) zeolite concentration, SOD concentration, and oxidation current peak.

to improve the current peaks might be due to the hydrophilic nature of the-OH group around the pores making it suitable for the immobilization of enzymes. The order and pore structure of zeolite, which are uniform, result in high selectivity and reproducibility (Valdes et al., 2006). In addition, the uniqueness posed by zeolite is its catalytic activity that can help accelerate the reaction (Dai et al., 2003).

\section{Optimization of immobilized SOD activity}

Figure 2 shows the contour plots of immobilized SOD extract activity. All plots show optimum activity within the darkest area. The optimized parameters were $\mathrm{pH}(7-11)$, temperature $\left(20^{\circ} \mathrm{C}-40^{\circ} \mathrm{C}\right)$, zeolite mass $(25-250 \mathrm{mg})$, and SOD concentration (1-5 unit $/ \mathrm{ml}$ ). The optimum conditions for immobilized $D$. radiodurans $\mathrm{SOD}$ were at $30^{\circ} \mathrm{C}, \mathrm{pH} 9,137.5 \mathrm{mg}$ zeolite, and 1,500 $\mu \mathrm{g} / \mathrm{ml}$ SOD concentration. Meanwhile, the optimum conditions for immobilized pure SOD were $\mathrm{pH} 9,30^{\circ} \mathrm{C}, 137.5 \mathrm{mg}$ zeolite mass, and 3 units $/ \mathrm{ml}$ SOD concentration.

These results differ slightly from the previous study (Iswantini et al., 2013), where immobilized SOD was optimum at $20^{\circ} \mathrm{C}$ and $\mathrm{pH}$ 11. Campanella et al. (2001) immobilized SOD in kappa-carrageenan gel with optimum conditions at $25^{\circ} \mathrm{C}$ and $\mathrm{pH}$ 7.5. Another study (Di et al., 2004), showed the optimum condition for SOD activity immobilized on the surface of a gold electrode was at $\mathrm{pH}$ 8.2. But in general, immobilized SOD activity is optimum in an alkaline environment. The different results obtained might be due to the different immobilization methods used.
Optimized parameters of SOD D. radiodurans activity were $\mathrm{pH}(7-11)$, temperature $\left(20^{\circ} \mathrm{C}-40^{\circ} \mathrm{C}\right)$, and zeolite $(25-250$ $\mathrm{mg}$ ). Concentration of $D$. radiodurans was $62.8 \mathrm{mg} / \mathrm{ml}$. Figure 3 shows contour plots for the relationships between $\mathrm{pH}$, temperature, and zeolite and $D$. radiodurans activity exhibited by immobilized $D$. radiodurans whole-cells. These plots show that maximum values were not obtained. It can be said that $D$. radiodurans did not have the activity necessary to increase the oxidation peak.

Deinococcus radiodurans is a gram-positive bacterium with 1.5-3.5 $\mu \mathrm{m}$ diameter length and tetrad-shape. Deinococcus radiodurans has thick cell walls, which makes it possible that there was no SOD reaction to superoxide radicals, so electron transfer did not occur and there was no current response. Based on these results, we may conclude that whole-cells of $D$. radiodurans have less potential for utilization as biological recognition components in antioxidant biosensors.

\section{Enzyme kinetics of immobilized SOD}

To study the specificity of $D$. radiodurans SOD protein crude extract immobilized onto modified carbon paste electrodes, we determined the enzymatic kinetic properties for this enzyme, i.e., apparent Michaelis-Menten constant $\left(K_{m}^{\mathrm{app}}\right)$ and apparent maximum rate $\left(V_{\max }^{\text {app }}\right)$ which was analogous with apparent maximum current $\left(I_{\max }^{\mathrm{app}}\right)$. Figure 4 shows a Lineweaver-Burk curve, while the relationship between $\frac{1}{\text { [xanthine }]}$ and $\frac{1}{\Delta I_{\mathrm{ap}}} \cdot K_{m}^{\mathrm{app}}$ and $I_{\max }^{\text {app }}$ values are shown in Table 2.

The $K_{m}^{\text {app }}$ in Table 2 shows the $K_{m}^{\text {app }}$ value for pure SOD is higher than the $K_{m}^{\text {app }}$ value for SOD protein crude extract. The small $I_{\max }^{\text {app }}$ and $K_{m}^{\text {app }}$ values indicate the catalytic reaction rate of SOD reaction is catalyzed faster by $D$. radiodurans SOD than by pure SOD.

Table 2. Kinetic parameter values of immobilized SOD.

\begin{tabular}{ccccc}
\hline \multirow{2}{*}{ Method } & \multicolumn{2}{c}{ Pure SOD } & \multicolumn{2}{c}{ Deinococcus radiodurans SOD } \\
\cline { 2 - 5 } & $(\boldsymbol{\mu A})$ & $(\mathbf{m M})$ & $(\boldsymbol{\mu A})$ & $(\mathbf{m M})$ \\
\hline Lineweaver-Burk & 0.197 & 0.510 & 0.265 & 0.340 \\
\hline$K_{m}^{\text {app }}=$ Apparent Michaelis-Menten constant; $I_{\max }^{\text {app }}$ & $=$ Apparent maximum current.
\end{tabular}
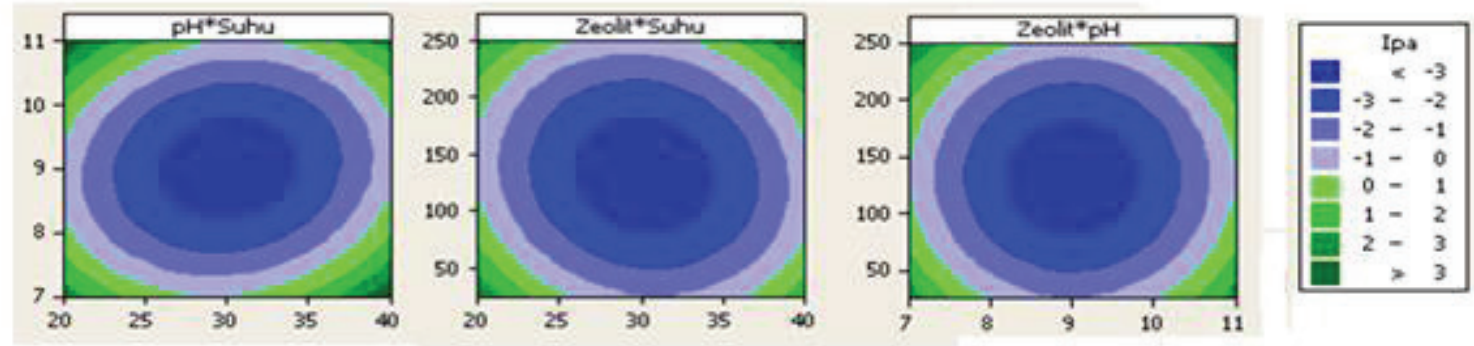

Figure 3. Contour plots of condition optimization for SOD activity exhibited by immobilized $D$. radioduranas whole-cells, relationships between (from left to right) $\mathrm{pH}$, temperature, and oxidation current peak; zeolite, temperature, and oxidation current peak; and zeolite, $\mathrm{pH}$, and oxidation current peak. 


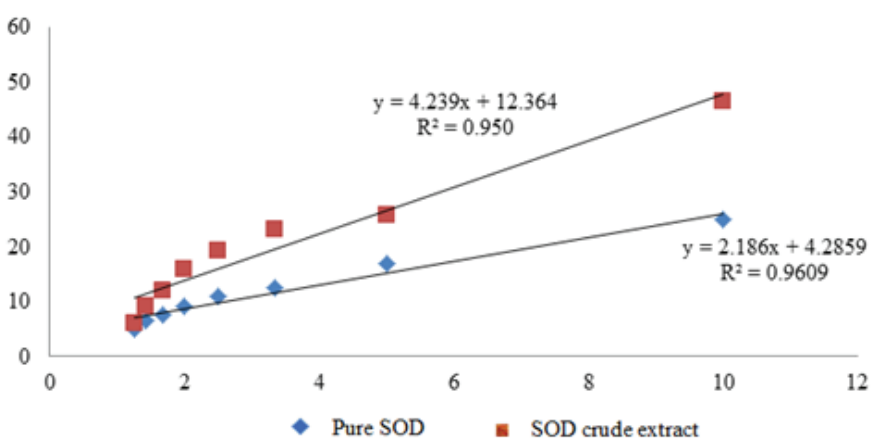

Figure 4. Lineweaver-burk plots for immobilized pure SOD $(\diamond)$ and $D$. radiodurans SOD crude extract ( $\square$ ).

The difference in $K_{m}$ values was caused by differences in the structure of the SOD enzymes from bovine erythrocyte SOD and those produced by $D$. radiodurans. The bovine erythrocyte SOD produced is the Cu-Zn SOD type (Kankofer, 2002; Misra and Fridovich, 1971), while on D. radiodurans, it is Mn-SOD. The values of pure enzyme and SOD extract are greater than those resulting from the previous study (Iswantini et al., 2013), where the $K_{m}$ values for pure SOD and SOD extract were 0.3694 and 0.1930 , respectively. $K_{m}$ value is a parameter of the enzyme-substrate binding affinity, if the $K_{m}$ value is low, the enzyme binds strongly to the substrate, so a low concentration of substrate is enough to saturate the enzyme and vice versa. From these results, we may conclude that the current response can be improved in the presence of zeolite, but this can also cause an increase in the $K_{m}$ value. This is probably due to not all of the SODs being immobilized in zeolite while stirring for 24 hours, meaning the SODs involved in superoxide radical reactions were less concentrated than those in the previous study (Iswantini et al., 2013).

\section{CONCLUSION}

The use of zeolite as a co-immobilization material for SOD immobilized on the surface of carbon paste electrodes modified with ferrocene as a mediator could increase SOD activity in antioxidant biosensors. SOD extract showed a higher affinity than that of pure SOD. Further research is necessary to determine other parameters or analytical properties such as sensitivity, linearity, stability, recovery, repeatability, reproducibility, and accuracy.

\section{CONFLICT OF INTERESTS}

Authors declare that there is no conflict of interest.

\section{FINANCIAL SUPPORT}

None.

\section{REFERENCES}

Azizi SN, Ranjbar S, Raoof JB, Hamidi-Asl E. Preparation of $\mathrm{Ag} / \mathrm{NaA}$ zeolite modified carbon paste electrode as a DNA biosensor. Sens Act B Chem, 2013; 181:319-25.

Balal K, Mohammad H, Bahareh B, Ali B, Maryam H, Mozhgan Z. Zeolite nanoparticle modified carbon paste electrode as a biosensor for simultaneous determination of dopamine and tryptophan. J Chin Chem Soc, 2009; 56(4):789-96.

Battista JR. Against all odds: the survival strategies of Deinococcus radiodurans. Annu Rev Micro, 1997; 51:203-24.

Braik M, Barsan MM, Dridi C, Ben Ali M, Brett CMA. Highly sensitive amperometric enzyme biosensor for detection superoxide based on conducting polymer/CNT modified electrode and superoxide dismutase. Sens Act B Chem, 2016; 236:574-82.

Busch JLHC, Hrncirik K, Bulukin E, Boucon C, Mascini M. Biosensor measurements of polar phenolics for the assessment of bitterness and pungency of virgin olive oil. J Agric Food Chem, 2006; 54(12):4371-7.

Cabaj J, Jedrychowska A, Swist A, Soloducho J. Tyrosinase biosensor for antioxidant based on semiconducting polymer support. Electroanal, 2016; 28:1383-90.

Campanella L, Bonanni A, Finotti E, Tomassetti M. Biosensors for determination of total and natural antioxidant capacity of red and white wines: Comparison with other spectrophotometric and fluorimetric methods. Biosens Bioelectron, 2004; 19:641-51.

Campanella L, Bonanni A, Tomassetti M. Determination of the antioxidant capacity of samples of different types of tea, or of beverages based on tea or other herbal products, using a superoxide dismutase biosensor. J Pharm Biomed Anal, 2003; 32(4-5):725-36.

Campanella L, Favero G, Persi M, Tomassetti M. Evaluation of radical scavenging properties of several plants, fresh or from herbalists, using a superoxide dismutase biosensor. J Pharm Biomed Anal, 2001; 24(56):1055-64.

Campanella L, Martini E, Tomassetti M. Antioxidant capacity of the algae using a biosensor method. Talanta, 2005; 66(4):902-11.

Cortina-Puig M, Camp M. Electrochemical biosensors as a tool for antioxidant capacity assessment. J Sens Actua, 2007; 129:459-66.

Dai Z, Liu S, Ju H. Direct electron transfer of cytochrome c immobilized on $\mathrm{NaY}$ zeolite matrix and its application in biosensing. J Elect Acta, 2003; 49(13):2139-44.

Di J, Bi S, Zhang M. Third-generation superoxide anion sensor based on superoxide dismutase directly immobilized by sol-gel thin film on gold electrode. Biosens Bioelectron, 2004; 19(11):1479-86.

Garcia LF, Benjamin SR, Marreto RN, Lopes FM, Golveia JCDS, Fernandes NC, Santiago MF, Gil EDS. Laccase carbon paste based biosensor for antioxidant capacity. The effects of different modifiers. Int J Electrochem Sci, 2015; 10:5650-60.

Iswantini D, Trivadila, Nurhidayat N, Nurcholis W. Antioxidant biosensor using microbe. WASET, 2013; 78:1272-9.

Kamel AH, Moreira FTC, Almeida SAA, Sales MGF. Novel potentiometric sensors of molecular imprinted polymers for specific binding chlormequat. Electroanal, 2008; 20(2):194-202.

Kankofer M. Superoxide dismutase and glutathione peroxidase activities in bovine placenta: spectrophotometric and electrophoretic analysis. Revue Med Vet, 2002; 153:121-4.

Liu B, Yan F, Kong J, Deng J. A reagentless amperometric biosensor based on the coimmobilization of horseradish peroxidase and methylene green in a modified zeolite matrix. Anal Chim Acta, 1999; 386:31-9.

Misra HP, Fridovich I. The generation of superoxide radical during the autoxidation of ferredoxins. J Biol Chem, 1971; 22:6886-90.

Roy JJ, Abraham TE, Abhijith KS, Kumar PVS, Thakur MS. Biosensor for determination of phenols based on cross-linked enzyme crystals (CLEC) of laccase. Biosens Bioelectron, 2005; 21(1):201-11.

Saiapina OY, Pyeshkova VM, Soldatkin OO, Melnik VG, Kurc BA, Walcarius A, Dzyadevych SV, Jaffrezic-Renault N. Conductometric enzyme biosensor based on natural zeolite clinoptilolite for urea determination. J Mat Sci Eng, 2011; 31: 1490-7.

Seatovic S, Gligic L, Radulovic Z, Jacikov RM. Purification and partial characterization of SOD from thermophilic bacteria Thermoterix sp. J Serb Chem Soc, 2004; 96:9-16.

Takahashi H, Li B, Sasaki T, Miyazaki C, Kajino T, Inagaki $\mathrm{S}$. Immobilized enzymes in ordered mesoporous silica material and improvement of their stability and catalytic activity in organic solvent. J Micro Meso Mat, 2001; 44-45:755-62.

Tawaha K, Alali FQ, Gharaibeh M, Mohammad M, El-Elimat T. Antioxidant activity and total phenolic content of selected Jordanian plant species. Food Chem, 2007; 104:1372-8. 
Trivadila. Biosensor antioksidan menggunakan superoksida dismutase deinococcus radiodurans diimobilisasi pada permukaan electrode pasta karbon dan parameter kinetikanya. Postgraduate thesis, Bogor Agricultural University, Bogor, Indonesia, 2011.

Valdes MG, Perez-Cordoves AI, Diaz-Garcia ME. Zeolites and zeolite-based materials in analytical chemistry. J Trends Anal Chem, 2006; $25: 24-30$.

Wan J, Bi JL, Du P, Zhang S. Biosensor based on the biocatalysis of microperoxidase-11 in nanocomposite material of multiwalled carbon nanotubes/room temperature ionic liquid for amperometric determination of hydrogen peroxide. Anal Biochem, 2009; 386:256-61.

Yuan WY, Bing T, Yuejin H. A novel gene of Deinococcus radiodurans responsible for oxidative stress. J Chin Sci Bull, 2007; 15:2081-7.
Zimmerman JM, Battista JR. A ring-like nucleoid is not necessary for radioresistance in the Deicococcaceae. BMC Microbiol, 2005; 5:17.

How to cite this article:

Iswantini D, Weniarti, Nurhidayat N, Abidin Z, Trivadila. Antioxidant biosensor based on superoxide dismutase from Indonesian microbes immobilized in Indonesian natural zeolite. J Appl Pharm Sci, 2019; 9(04):104-109. 